\title{
Keeping it Clean: Cleaning Your Refrigerator ${ }^{1}$
}

Mary N. Harrison ${ }^{2}$

\section{Supplies Needed}

- Dishwashing detergent

- Baking soda

- Rags or sponge

- Vacuum cleaner

\section{Daily}

- Immediately wipe up spills in your refrigerator.

- Cover all food and drinks stored in the refrigerator. Use plastic wrap or a lid to keep the food from drying out and to eliminate bad odors.

\section{Monthly or as Needed}

- Turn the temperature controls to the "off" position.

- Remove everything in the refrigerator. Put it in a cool place.

- Throw out any old or spoiled food.

- Remove and wash shelves with warm soapy water.

-Wipe all inside walls of the refrigerator. Use a damp sponge or cloth. Rinse the rag or sponge often in sudsy water to keep it clean.
- Dry the walls with a clean cloth.

- Dry shelves and replace then in the refrigerator.

- Wipe off the rubber gasket around the door using a damp cloth.

- Remove the vegetable and meat trays in the refrigerator. Wash and dry them. Return them to the refrigerator.

- Put the usable foods back in the refrigerator.

- Reset the temperature controls. Close the door.

- Using soapy water and a sponge or cloth wipe the outside door and handles of the refrigerator. Scrub dirty spots and fingerprints with baking soda.

- Slide the drip tray from under the refrigerator. Wash the tray in sudsy water. Dry off the tray and put it back.

- Vacuum the cooling coils. The coils may be in the back of the refrigerator or underneath it.

1. This document is FCS5232-08, one of a series of the Department of Family, Youth and Community Sciences, Florida Cooperative Extension Service, Institute of Food and Agriculture Sciences, University of Florida. Publication: May 2002. Revised: December 2005. Please visit the EDIS Web site at http://edis.ifas.ufl.edu

2. Mary N. Harrison, professor, Department of Family, Youth and Community Sciences, Cooperative Extension Service, Institute of Food and Agricultural Sciences, University of Florida, Gainesville, 32611.

The Institute of Food and Agricultural Sciences (IFAS) is an Equal Opportunity Institution authorized to provide research, educational information and other services only to individuals and institutions that function with non-discrimination with respect to race, creed, color, religion, age, disability, sex, sexual orientation, marital status, national origin, political opinions or affiliations. U.S. Department of Agriculture, Cooperative Extension Service, University of Florida, IFAS, Florida A. \& M. University Cooperative Extension Program, and Boards of County Commissioners Cooperating. Larry Arrington, Dean 